\title{
NSF to get big budget increase but not as much as it wants
}

\section{Washington}

THE US National Science Foundation (NSF) is set to receive a 9.8 per cent increase in its budget following agreement between House of Representatives and Senate appropriations committees. The appropriations bill, which gives NSF a total budget of $\$ 1,885$ million for fiscal year 1989, has now gone to the White House for signing.

Although the rise is only half that originally requested by the Reagan administration, it is above the current rate of inflation and should allow NSF some room for expansion. A big increase was earmarked for efforts to improve science and engineering education (22.8 per cent). But the bill refused NSF's request for a separate $\$ 150$ million budget, spread over five years, to fund the proposed new science and technology centres. The centres are intended to foster multidisciplinary collaborative research and help move the results of basic research from laboratory to industry. Hopes that

\section{French keeping their heads down}

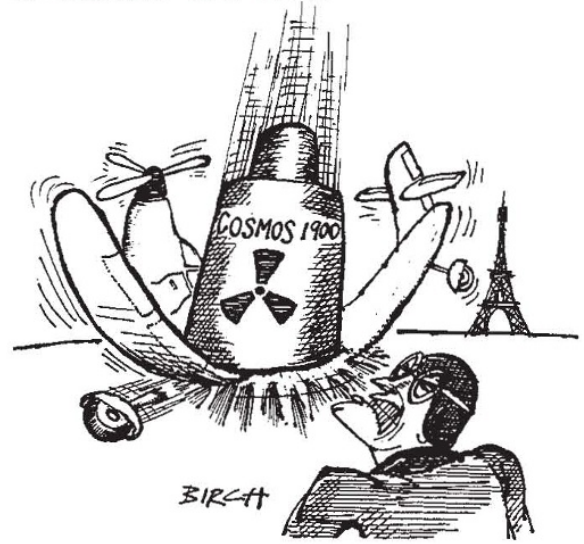

Paris

WHILE 300 gendarmes scan the night sky to try to pinpoint a mysterious small aircraft that has been skimming Paris rooftops for the past week, a number of government departments have been preparing contingency plans in case the wayward nuclear-powered satellite, COSMOS 1900, should crash on French soil. Although the risk is considered to be extremely low (about one in one thousand), joint emergency plans have been drawn up by the Civil Defence corps, the Atomic Energy Commission (CEA) and the Central Service for Protection against Ionizing Radiations (SCPRI). These include the mobilization of 35 helicopters, and telling the public to keep away from suspicious metal objects.

Peter Coles the first centres could be established this fiscal year have already been disappointed.

The appropriations bill does provide for "a limited number" of new centres to start up next year with funds from NSF's core $\$ 1,583$ million appropriation for research and related activities.

That account provides support for individual researchers as well as for already-established science and engineering centres, supercomputer centres and many other programmes. NSF is expected to decide soon how much it can spare towards the new centres and how many of the fifty proposals it has already received can be supported.

An upper limit is eventually likely to be set in the authorization bills which direct how appropriated funds may be spent. Both House and Senate authorization bills failed to complete passage before the summer recess. At present, the Senate version authorizes expenditure on science and technology centres in fiscal year 1989 of $\$ 30$ million, and the House version authorizes $\$ 20$ million. Compromise will have to be found on this issue and that of whether a new ice-breaker ship for the Antarctic Program should be built in the United States or ordered from abroad at a lower cost (see Nature 330, 789; 1988). The appropriations bill suggests that the ice-breaker should be built in the United States unless the cost is more than 50 per cent greater than that for a foreign ship.

\section{Liberal stance on embryo experiments} Sydney

NEw South Wales has been urged to adopt less stringent regulations on in vitro fertilization research than the controversial regulations agreed in the neighbouring state of Victoria.

In a report presented by the New South Wales Law Reform Commission to the state parliament, the commission urges that all types of research on human embryos be permitted until 14 days after fertilization, the usual time of implantation. In Victoria, research is limited to a 22-hour period after fertilization.

Important reasons behind the committee's liberal stance were acceptance of the proposition that embryos need not necessarily be given the full rights accorded to people, and the realization that the poor success rate of in vitro fertilization techniques can be improved only through further experiments.
Charles Morgan

\section{Indian earthquake}

\section{Washington}

LAST Sunday's earthquake in the Indian state of Bihar, near the Nepalese border, had a magnitude of at least 6.5 on the Richter scale and, according to early reports, has killed as many as a thousand people. At least 100,000 homes have been destroyed by the earthquake. Reports from rural regions have not been received yet and are bound to push the death toll even higher.

The earthquake was registered on seismographs at US Geological Survey stations and was officially estimated at 6.7 on the Richter scale. Estimates from New Delhi were slightly lower.

The earthquake occurred on the same fault line, in the Himalayan foothills, as the magnitude 8.3 earthquake that killed 7,500 people in 1934. In most parts of the world, an earthquake of magnitude 8.0 or more would be expected to relieve most of the geological stress in the area, and thus lead to a fairly quiet period lasting perhaps for centuries. But at the Himalayas, where the Indian subcontinent is running into Asia, the relative motion of the continental plates is extremely rapid - close to two inches a year. According to Bruce Bolt of the University of California, the 50-year interval between the 1934 earthquake and last week's cannot be called unusually small.

The death toll from Himalayan earthquakes is much higher than would occur in California, for example, where similar shocks have been registered. The San Francisco earthquake of 1906 was of magnitude 8.3, and killed about 700 people; a 1971 earthquake in the San Fernando valley, with magnitude 6.7, killed 63. The difference is partly explained by the higher density of population in India and partly by the topography: Himalayan earthquakes frequently trigger large landslides.

The Indian government has been making attempts in recent years to educate the population about earthquakes and to implement new safety codes for buildings, but poverty and the remoteness of the population centres make earthquake awareness programmes of California sophistication impossible. An earthquake of magnitude 8 or greater occurring in the Bihar-Nepal region today might, according to some experts, cause up to a million deaths.

With the help of the United States, India has begun to install a network of strongmotion accelerometers along its northern borders. A number of high dams have been built in the Himalayan foothills over the past few years, and the Indian government is concerned to protect its investment by studying the pattern of seismicity in the area, as well as to provide earthquake warnings for lower inhabitants.

David Lindley 